\title{
Detection and molecular characterization of respiratory viruses that cause acute respiratory infection in the adult population
}

\author{
Dylan Lucía Díaz-Chiguer ${ }^{*}$, Rocío Tirado-Mendoza², Adrián Márquez-Navarro³, Javier Rolando \\ Ambrosio-Hernández², Ismael Ruiz-Fraga1, Ricardo Ezequiel Aguilar-Vargas', José Manuel Lira-Martínez² \\ and Julio César López-Valdés \\ ${ }^{1}$ Medical Directorate, Instituto de Seguridad y Servicios Sociales de los Trabajadores del Estado, Ciudad de México; ${ }^{2}$ Department of Microbiology \\ and Parasitology, UNAM Medicine, City of Mexico; ${ }^{3}$ Department of New and Generic Drugs, Comisión Federal Para la Protección Contra Riesgos \\ Sanitarios, Ciudad de México; ${ }^{4}$ Faculty of Medicine of Tampico, Universidad Autónoma de Tamaulipas Dr. Alberto Romo Caballero, Tampico, \\ Tamaulipas. Mexico
}

\begin{abstract}
Introduction: Acute respiratory infections are one of the main causes of morbidity and mortality in older adults and patients with chronic diseases. Among the responsible etiological agents are human respiratory viruses, such as: respiratory syncytial virus, parainfluenza virus and metapneumovirus. Objective: To carry out a differential diagnostic study of respiratory viruses circulating and co-circulating in an adult population. Methods: A pilot study was conducted in patients older than 18 years, who presented signs and symptoms suggestive of acute respiratory infection and whose clinical picture did not exceed 15 days of evolution; end-point polymerase chain reaction assays were performed with the use of specific oligonucleotides for molecular diagnosis. Results: 72 specimens of patients with an age of $51.33 \pm 19.33$ years, with a predominance of females (4.5:1); original inhabitants of Mexico City; only 22 were positive for respiratory viruses, being mostly metapneumovirus infections. Conclusions: The knowledge of the circulating viral strains in the population will allow to determine changes that can declare an epidemiological alert leading to the best decision making for the benefit of the patients.
\end{abstract}

KEY WORDS: Acute respiratory infections. Respiratory viruses. Molecular diagnosis.

\section{Introduction}

Acute respiratory infections (ARI) are the most common nosological entity during the life of the human being. The World Health Organization (WHO) recognizes that some ARIs cause large scale outbreaks, with high morbidity and mortality; therefore, they constitute an emergency for public health 1 . In Mexico, more than 26 million new cases were reported through the Ministry of Health in 2017; approximately 1.6 million of these cases corresponded to the population of beneficiaries of the Institute of Social Security and Services of State Workers (ISSSTE Instituto de Seguridad y Servicios Sociales de los Trabajadores del Estado)2.
Although most respiratory infections only affect the upper respiratory tract (common cold, rhinitis and pharyngotonsillitis), around $5 \%$ of infections are estimated to be able to affect the lower respiratory tract and cause diseases that may require hospital admission (bronchitis, bronchiolitis and pneumonia) ${ }^{3}$.

In the children's population, respiratory viruses (RV) are the most common cause of serious respiratory insufficiency ${ }^{4}$. Furthermore, recent studies have shown that the figures of both morbidity and mortality related to these infections have increased for the adult population and for older adults with immune compromise or cardiopulmonary conditions ${ }^{5,6}$.

Among the RVs that have been recognized as ARI causative agents are influenza viruses $A$ and $B$,
Correspondence:

*Dylan Lucía Díaz-Chiguer

E-mail: dra.dylandiaz@outlook.com
Date of reception: 06-03-2019

Date of acceptance: 19-03-2019

DOI: 10.24875/GMM.M19000282
Gac Med Mex. 2019;155 (Suppl 1):S7-S12

Contents available at PubMed www.gacetamedicademexico.com 
parainfluenza viruses 1, 2, 3 and 4 (HPIV 1-4), human metapneumovirus (HMPV), human respiratory syncytial virus (HRSV), rhinovirus and enterovirus. Most of them are classified within the Paramixoviridae family, genus pneumovirus (HRSV and HMPV) and paramyxovirus (HPIV 1-3) ${ }^{7,8}$, are highly contagious and are responsible for annual epidemics, mainly during the winter period ${ }^{9}$. Now, in the case of HRSV, it is estimated to be responsible 33.8 million ARIs, as well as 3.4 million hospital admissions and 250,000 deaths per year. It has been associated with $70 \%$ of bronchiolitis and $25 \%$ of pneumonia cases as severe complications, while HMPV and HPIV 1-3 are responsible for $5-15 \%$ of ARIs and $2-17 \%$ of hospital admissions ${ }^{1}$. It should be noted that HMPV is considered an emerging virus and shows a high prevalence in hospitalized pediatric patients with bronchopneumonia and in adults ${ }^{5,6}$.

Despite the importance of the issue demonstrated by the aforementioned data, there is no yet a reliable diagnostic and systematically used method for the rapid detection of HRSV, HMPV and PIV1-3.

Current tools for ARI diagnosis (serology, cell culture virus isolates and immunofluorescence) are of low sensitivity. According to the above, developing molecular diagnostic methods that offer higher sensitivity and specificity in comparison with the previously described methods is considered to be of the utmost importance. Accordingly, a study was conducted aiming to diagnose and characterize, by means of polymerase chain reaction (PCR) molecular techniques, the RVs that circulate and cocirculate in an adult population diagnosed with ARI according to the Clinical Practice Guidelines criteria ${ }^{10,11}$.

\section{Methods}

A cross-sectional pilot study was carried out at the ISSSTE Indianilla Specialty Clinic of Mexico City in the period encompassed between August 2016 and March 2017. Patients older than 18 years, who showed signs and symptoms suggestive of ARI and whose condition did not exceed 15 days of evolution were included. In contrast, patients who showed signs and symptoms consistent with bacterial infection, who received antibiotic therapy or antiviral drugs during the preceding 7 days, as well as those who showed criteria consistent with severity on physical examination (e.g., dyspnea at rest, peripheral cyanosis, tachycardia, tachypnea) and whose signs and symptoms could be attributed to other diagnoses such as allergic rhinitis or chronic sinusitis were excluded.
It should be noted that this clinic looks after approximately 26,000 patients annually in continued medical care, as well as providing 92,000 (approximately) specialized care consultations (e.g., otorhinolaryngology, pulmonology and inhalation therapy) to patients referred from 18 family medicine clinics of Mexico City and the State of Mexico.

In order to carry out the investigation, authorization was obtained from the Research Committee, as well as the Ethics Committee belonging to the institution, which included the biosafety conditions for handling biological samples and/or isolated pathogen microorganisms according to the protocols established by the NOM-087SEMARMAT-SSA1-2002 standard, "Environmental Protection, Environmental Health, Classification and Specialization in the Management of Hazardous Infectious Biological Residues that are generated in establishments that provide medical attention".

\section{Data collection}

A questionnaire was applied in order to find out data consistent with ARI, such as: temperature higher than $37.5^{\circ} \mathrm{C}$, cough with or without expectoration, odynophagia, dysphonia, malaise, sneezing, arthralgia, myalgia, dyspnea, tonsillitis, rales, wheezing, rhinorrhea, among others. In addition, history was taken in order to verify the absence of self-medication with antibiotics or antiviral drugs for 7 days prior to the study; subsequently, a specimen was taken by pharyngeal and tonsillar swab. Data collection was manual, daily, with subsequent review of the correct filling of each instrument.

\section{Method for obtaining the sample}

Prior of taking the sample, it was made sure that the candidates did not have oral hygiene prior to attending the clinic. In sterile conditions, with a tongue depressor, the patient's tongue was held, and firmly rubbed the posterior wall of the oropharynx with a dry and sterile cotton swab, trying to obtain the highest number of cells. The swab with the specimen was placed in a sterile plastic tube that contained a transport medium (DMEM culture medium supplemented with $5 \%$ bovine serum albumin, $1 \%$ glutamine and $1 \%$ penicillin), which was kept at $4^{\circ} \mathrm{C}$ until processed for viral isolation and genotyping. Once isolation was carried out, it was preserved at $-70^{\circ} \mathrm{C}$. 
Table 1. List of HVSR F, GA and MLGB genes, HMPV N and L genes and HPIV 2 HN gene oligonucleotides and sequences

\begin{tabular}{|c|c|c|c|c|c|}
\hline Gene/sense & Sequence & Gene & Fragment size (bp) & Gene region & Alignment temperature $\left({ }^{\circ} \mathrm{C}\right)$ \\
\hline \multicolumn{6}{|c|}{ Oligonucleotides for HRSV } \\
\hline $\mathrm{Ff}$ & 5'ATG'AACAGTTTAACATTACCAAGTGA3' & \multirow[t]{2}{*}{$\mathrm{F}$} & \multirow[t]{2}{*}{193} & \multirow[t]{2}{*}{$1127-1320$} & \multirow[t]{2}{*}{56} \\
\hline $\mathrm{Fr}$ & 5'CCACGATTTTTATTGGATGCTG3' & & & & \\
\hline Gf & 5'СCСААСАТАССТСАСТ3' & \multirow[t]{2}{*}{$G(A)$} & \multirow[t]{2}{*}{549} & \multirow[t]{2}{*}{$275-524$} & \multirow[t]{2}{*}{55} \\
\hline $\mathrm{Gr}$ & 5'GAGGAGGTTGAGTGGAAG3' & & & & \\
\hline MLf & 5'CATGCCAAACACAAGAATCAAC3' & \multirow[t]{2}{*}{$M L(B)$} & \multirow[t]{2}{*}{106} & \multirow[t]{2}{*}{$102-204$} & \multirow[t]{2}{*}{58} \\
\hline MLr & 5'АTTCATCATCTCTGCСАATCAC3' & & & & \\
\hline \multicolumn{6}{|c|}{ Oligonucleotides for HMPV } \\
\hline $\mathrm{Nf}$ & 5'-CAACAGCAGTGACACCCTC-3' & \multirow[t]{2}{*}{ N } & \multirow[t]{2}{*}{599} & \multirow[t]{2}{*}{$148-747$} & \multirow[t]{2}{*}{60} \\
\hline $\mathrm{Nr}$ & 3'-ACTCATACCGTTTCGTAA-5' & & & & \\
\hline Lf & 5'-GCCATAGCCCAAACCATA- 3' & \multirow[t]{2}{*}{ L } & \multirow[t]{2}{*}{447} & \multirow[t]{2}{*}{ 8920-9367 } & \multirow[t]{2}{*}{66} \\
\hline Lr & 3'-CCCTGTAACGACTAGACT-5' & & & & \\
\hline \multicolumn{6}{|c|}{ Oligonucleotides for HPIV 2} \\
\hline $\mathrm{HnF}$ & 5'-GACGCCTAAATATGGACCTCTC-3' & \multirow[t]{2}{*}{$\mathrm{HN}$} & \multirow[t]{2}{*}{279} & \multirow[t]{2}{*}{$525-826$} & \multirow[t]{2}{*}{68.8} \\
\hline $\mathrm{HNr}$ & 5'-CACGTCTGGTCTTCCATCTTT-3' & & & & \\
\hline
\end{tabular}

\section{Respiratory viruses genotyping}

In order to identify and confirm the RVs in the specimens, as well as in positive controls, endpoint polymerase chain reaction (RT-PCR) assays were carried out with the use of specific oligonucleotides especially designed for each one of the viruses under study (Table 1); for HRSV, the F (fusion) genes and for subgroups $A$ or $B$ subtyping, the $G$ (binding) or $M L$ genes were amplified, respectively; for HMPV, the N (nucleocapsid) and L (RNA polymerase) genes, while for HPIV 2, the HN gene (hemagglutinin-neuraminidase).

For the design of the oligonucleotides, the OligoAnalyzer ${ }^{\circledR}$ V 3.1 program was used, and was based on the consensus sequence constructed from viral isolates complete sequences of the four subtypes reported in Genbank: A1 (KC588902.1), A2 (FJ168779.1), B1 (AY525843.1) and B2 (FJ168778.1) of HMPV. For HRSV, subgroup A Long strain (NC_001781.1 and AY911262.1); HRSV subgroup B 18537 strain (GenBank: D00397.1) and for HPIV (AB367954). Subsequently, the alignments were carried out with the Clustal Omega EMBL-EBI program. In addition, the formation of dimers or secondary structures and alignments was examined using BLAST with the NCBI nucleotide sequence database, whereby alignments with genes from other organisms or with regions were discarded. The molecular markers (oligonucleotides) designed in the laboratory to carry out the viral differential diagnosis (HRSV, HMPV and/or HPIV 2), allow including the viral types and viral variants that are circulating in the study population.

\section{Statistical analysis}

The obtained data were analyzed with the SPSS ${ }^{\oplus}$ Statistics program (Version 19), using the $\chi^{2}$ (chisquare) test for quantitative variables, with statistical significance being considered when a $p$-value $<0.05$ was obtained. Samples that lacked the required data and/or those clinical samples that, under our selection criteria for viral isolation, were contaminated with bacteria, were regarded as "lost elements".

\section{Results}

\section{Stage I. Viral characterization}

During the study period, 72 specimens were obtained by pharyngeal exudate from patients with clinical diagnosis of ARI, out of which only $22(30.55 \%)$ met the inclusion criteria and had a complete medical 
Table 2. Demographic results and RT-PCR-isolated viruses in respiratory infection cases

\begin{tabular}{|l|c|c|}
\hline Age range & Frequency & $\%$ \\
\hline $15-25$ & 3 & 14 \\
\hline $26-40$ & 3 & 14 \\
\hline $41-55$ & 6 & 27 \\
\hline $56-70$ & 6 & 27 \\
\hline $71-90$ & 4 & 18 \\
\hline Total & 22 & 100 \\
\hline Virus type & Frequency & $\%$ \\
\hline HMPV & 10 & 45.6 \\
\hline HPIV 2 & 1 & 4.5 \\
\hline HSRV, HMPV & 1 & 4.5 \\
\hline HSRV, HMPV, HPIV 2 & 3 & 13.7 \\
\hline HSRV, HPIV 2 & 1 & 4.5 \\
\hline HSRV, HMPV & 1 & 4.5 \\
\hline HSRV-B & 5 & 22.7 \\
\hline Total & 22 & 100 \\
\hline HMPV: human metapneumovirus; HPIV 2: human parainfluenza virus 2; HRSV: human \\
respiratory syncytial virus.
\end{tabular}

history supporting their epidemiological information. Demographic data showed a mean age of 51.33 years (SD \pm 19.33 ), with predominance of the female gender (4.5:1), with the population entirely originating from Mexico City (Table 2). Of all the studied cases, it was the female gender that yielded a larger number of ARI-positive cases $(81.81 \%)$, while the male gender accounted for $18.18 \%(p<0.05)$. The endpoint RT-PCR analysis showed that $45.45 \%$ of specimens were positive for HMPV, $22.72 \%$ for HRSV and only 1 case $(4.52 \%)$ for HPIV 2. There was coinfection in $27.27 \%$ of patients.

\section{Stage II. Clinical correlation}

The different signs and symptoms presented by the study patients were correlated. Given the results, it is possible to assert that the individual presence HMPV, as ARI causative agent, is responsible for the highest percentage of patients who experienced clinical manifestations; however, HSRV and HPIV 1-3 co-infection revealed a more severe clinical presentation (laryngeal stridor and dyspnea, 67 and $40 \%$, respectively) (Table 3).

On the other hand, HSRV was the second most common agent as well as the main responsible for rales
(40\%), wheezing (40\%), cough (31\%), headache (15\%) and poor general condition (25\%). On the other hand, in the case of coinfections, mainly those in which the three viral agents were identified, association was found with laryngeal stridor, wheezing, dyspnea, fever, rales, odynophagia, tonsillitis and nasal congestion.

\section{Discussion}

As in the entire world, respiratory infections in Mexico are a serious health problem. We consider that knowing in greater detail the viral agents that cause ARIs will somehow strengthen the efforts that have been made to reduce these infections in our country.

In an era of threats for communicable diseases emergence and reemergence, the importance of measures for prevention, control, diagnosis and treatment of infection in health care settings to prevent the occurrence and increase of outbreaks should not be underestimated. Among such concerns, it is recognized that although children require efficient detection of viruses such as human metapneumovirus and human coronavirus, screening has to be extended to adult patients as well ${ }^{6,12}$. Currently, molecular detection and characterization of the viral pathogens present in respiratory diseases is one of the most important challenges related to infectious diseases.

In the present study, we were able to assess the role of viral agents in ARIs in an adult outpatient population belonging to a secondary care clinic in Mexico City, where a high presence of "uncommon" RVs, such as HSRV, HMPV and HPIV 2 was detected. We should note that the presence of these pathogens is indistinguishable between each other, only being differentiated by the magnitude of clinical symptoms.

Currently, identification of the etiologic viral agent in respiratory infections is carried out using traditional methods such as viral isolation in cell cultures and direct or indirect immunofluorescence in clinical samples However, the use of these techniques has several disadvantages, including: a) several days or weeks are required for isolation in cell cultures; $b$ ) differences in cytopathic activity, which leads to the masking of less cytopathic and/or slow-growing viruses; c) poor sensitivity/specificity; d) false negatives when the immunofluorescence technique is used; e) viral isolation depends on the quality of the sample, and f) bacterial contamination during sample taking. For this reason, implementation of viral diagnostic strategies, such as those used in this study, is considered necessary, in 
Table 3. Frequency of symptoms and signs according to the type of infection

\begin{tabular}{|c|c|c|c|c|c|c|}
\hline \multirow[t]{2}{*}{ Clinical manifestation } & \multicolumn{6}{|c|}{ Vital infection (\%) } \\
\hline & $\begin{array}{c}\text { Coinfection } \\
\text { (HSRV, HMPV, HPIV 2) }\end{array}$ & $\begin{array}{l}\text { Coinfection } \\
\text { (HSRV, HMPV) }\end{array}$ & $\begin{array}{l}\text { Coinfection } \\
\text { (HSRV, HPIV 2) }\end{array}$ & SRV-B & HMPV & HPIV 2 \\
\hline $\begin{array}{l}\text { Symptoms } \\
\text { Fever } \\
\text { Headache } \\
\text { Poor general condition } \\
\text { Cough } \\
\text { Dyspnea } \\
\text { Cyanosis }\end{array}$ & $\begin{array}{c}50 \\
15 \\
0 \\
13 \\
40 \\
50\end{array}$ & $\begin{array}{c}0 \\
8 \\
12 \\
6 \\
20 \\
50\end{array}$ & $\begin{array}{c}0 \\
8 \\
13 \\
0 \\
20 \\
0\end{array}$ & $\begin{array}{c}0 \\
15 \\
25 \\
31 \\
20 \\
0\end{array}$ & $\begin{array}{c}50 \\
46 \\
50 \\
50 \\
0 \\
0\end{array}$ & $\begin{array}{l}0 \\
8 \\
0 \\
0 \\
0 \\
0\end{array}$ \\
\hline $\begin{array}{l}\text { URTI } \\
\text { Odynophagia } \\
\text { Hyaline rhinorrhea } \\
\text { Nasal congestion } \\
\text { Tonsillitis } \\
\text { Laryngeal stridor }\end{array}$ & $\begin{array}{c}9 \\
17 \\
15 \\
0 \\
67\end{array}$ & $\begin{array}{c}18 \\
12 \\
8 \\
20 \\
0\end{array}$ & $\begin{array}{l}0 \\
6 \\
8 \\
0 \\
0\end{array}$ & $\begin{array}{c}9 \\
18 \\
15 \\
20 \\
0\end{array}$ & $\begin{array}{l}64 \\
41 \\
46 \\
60 \\
33\end{array}$ & $\begin{array}{l}0 \\
6 \\
8 \\
0 \\
0\end{array}$ \\
\hline $\begin{array}{l}\text { LRTI } \\
\text { Rales } \\
\text { Wheezing }\end{array}$ & $\begin{array}{l}20 \\
40\end{array}$ & $\begin{array}{c}20 \\
0\end{array}$ & $\begin{array}{l}0 \\
0\end{array}$ & $\begin{array}{l}40 \\
40\end{array}$ & $\begin{array}{l}20 \\
20\end{array}$ & $\begin{array}{l}0 \\
0\end{array}$ \\
\hline Abdominal pain & 25 & 25 & 0 & 0 & 25 & 25 \\
\hline
\end{tabular}

URTI: upper respiratory tract infection; LRTI: lower respiratory tract infection.

order to improve the understanding and management of ARIs in this type of study population.

The results obtained show that from the design of own oligonucleotides, a good adequate identification of the paramyxovirus genus can be achieved. In addition, when associating these results with the clinical presentation of each case, they represent a tool for specific viral diagnosis; this was similar to results obtained in other epidemiological studies, where HMPV-produced disease is associated with ARI and COPD in adults ${ }^{13}$.

Additionally, as in previous reports, the fact that, in cases of viral coinfections, ARI-related clinical manifestations (cough, nasal congestion, rhinorrhea) tend to assume an overexpressed presentation stood out ${ }^{14}$.

Despite the limitations of this study, the results herein presented are of great interest, since the application of a molecular tool, such as endpoint RT-PCR, appears to offer the possibility to carry out the typing of the viral agents responsible for acute respiratory infection, which may constitute a support to clinical diagnosis. In addition, the use of this methodology can contribute to provide information for national epidemiological surveillance programs on seasonally circulating viruses in our country and to assess the appearance of viral variants that might have clinical relevance, thus allowing to direct the application of specific preventive measures for the control, diagnosis, prognosis and treatment of these infections, both in primary and secondary institutional care.

\section{Conclusions}

Establishing ARI rapid diagnosis is considered to be important, since this implies early treatment, as well as sanitary measures that prevent its dispersion to hospital settings and, more importantly, limiting antibiotic unnecessary use.

According to the results obtained from the differential viral diagnosis in the present study, the RVs of the paramyxovirus type remain circulating in the adult population; in addition, they may be present in the form of coinfections, which worsens the clinical presentation.

\section{Acknowledgments}

The present research work was supported by the ISSSTE E015 Health Research and Technological Development program and DGAPA-UNAM IN224316 and PE211115. The authors thank Dr. José Vicente Rosas Barrientos for his scientific advice, as well as B. Pharm. Karla Zárate Conde, María José Chávez Barajas, Daniel Alejandro Pérez Ayala and Ilse Joana Camacho Aguilar for their technical support.

\section{References}

1. Pio A, Leowski J, Luelmo F. Programa de la Organización Mundial de la Salud de infecciones respiratorias agudas en la infancia. Bol Of SanitPanam. 1984;96(4):283-93.

2. Secretaria de Salud. [internet] Anuario Estadístico 2016. Epidemiología. Disponible en www.epidemiologia.salud.gob.mx/anuario/ html/anuarios.

3. Wylie KM. The virome of the human respiratory tract. Clin Chest Med. 2017:38:11-9 
Gaceta Médica de México. 2019;155(Suppl 1)

4. Ogra PL. Respiratory syncytial virus: the virus, the disease and the immune response. Paediatr Respir Rev. 2004;5(Suppl A):S119-26.

5. Colosia AD, Yang J, Hillson E, Mauskopf J, Copley-Merriman C Shinde V, et al. The epidemiology of medically attended respiratory syncytial virus in older adults in the United States: A systematic review. PLoS One. 2017;12:e0182321.

6. Volling C, Hassan K, Mazzulli T, Green K, Al-Den A, Hunter P, et al. Respiratory syncytial virus infection-associated hospitalization in adults: a retrospective cohort study. BMC Infect Dis. 2014;14:665.

7. Mackay IM, Jacob KC, Woolhouse D, Waller K, Syrmis MW, Whiley DM et al. Molecular assays for detection of human metapneumovirus. J Clin Microbiol. 2003;41:100-5.

8. Fields B, Knipe DM, Howley PM. Virology. Philadelphia: Wolters Kluwer/ Lippincott Williams \& Wilkins; 2007.

9. Romero Feregrino R, Romero Feregrino R, Magaña IM, Romero CabeIlo R, González Saldaña NJ. Diagnóstico de Metapneumovirus humano. Revista de Enfermedades Infecciosas en Pediatría. 2013;26:256-69.
10. Visseaux B, Burdet C, Voiriot G, Lescure FX, Chougar T, Brugière O, et al. Prevalence of respiratory viruses among adults, by season, age, respiratory tract region and type of medical unit in Paris, France, from 2011 to 2016. 2017;12:e0180888.

11. Instituto Mexicano del Seguro Social. Guía de práctica clínica de diagnóstico y tratamiento de bronquiolitis aguda en niñas/niños y en el Primer Nivel de Atención. México; 2015.

12. Dayakar S, Pillai HR, Thulasi VP, Nair RR. Development of a multiplex RT-PCR for simultaneous diagnosis of human metapneumovirus (HMPV) and human respiratory syncytial virus (HRSV) from clinical specimens. 2016;27:375-81.

13. Stockton J, Stephenson I, Fleming D, Zambon MJ. Human metapneumovirus as a cause of community-acquired respiratory illness. 2002;8:897.

14. Martinello RA, Esper F, Weibel C, Ferguson D, Landry ML, Kahn JS. Human metapneumovirus and exacerbations of chronic obstructive pulmonary disease. 2006;53:248-54. 